\title{
Adatok a Bán-halom környezettörténeti és régészeti talajtani vizsgálatához
}

\author{
${ }^{1}$ Pető Ákos, ${ }^{1}$ BAKLAnov Szandra, ${ }^{2}$ TóTH Csaba,${ }^{3}$ TóTH Albert, ${ }^{1}$ BARCZI Attila \\ ${ }^{1}$ SZIE MKK, Természetvédelmi és Tájgazdálkodási Intézet, Gödöllő \\ ${ }^{2}$ DE, Természetföldrajzi és Geoinformatikai Tanszék, Debrecen \\ ${ }^{3}$ SZF, Vidékfejlesztési és Tájgazdálkodási Tanszék, Mezőtúr
}

\section{Bevezetés}

Talajaink számos funkciója közül az egyik, hogy kulturális és földrajzi környezetünk emlékeit mind fizikai valójukban, mind biológiai, kémiai és fizikai paraméterek formájában magukban hordozzák (RETALLACK, 2001; VÁRALLYAY, 2002). Ahhoz, hogy a talajokban kódolt környezeti - és sok esetben kulturális összefüggéseket is megvilágító ismeretekhez hozzájussunk, a természettudományok szerteágazó tárházából kell kiválasztanunk a célnak leginkább megfelelő módszertant (KOVÁCS, 2006; SZENDREI, 2012; FÜLEKY et al., 2015). Különösen igaz ez a kunhalmok esetében, amelyek mintegy "időkapszulaként" örzik az építésük elötti környezetük jellemzöit az alattuk eltemetett talajban (ALEXANDROVSKIY et al., 1997).

A földtani és kiemelten a paleotalajtani elemzésmódok mellett, a kunhalmok eltemetett talajszintjei lehetőséget adnak arra, hogy olyan paleoökológiai módszerekkel nyerjünk információt az egykori környezetről, amelyek közvetlenül az akkori vegetációra vonatkozóan szolgáltatnak adatokat (TóTH et al. 2014). A fitolitelemzés módszere a növényekben képződő hidratált szilícium-dioxid szemcsék vizsgálatára támaszkodik (PIPERNO, 2006). Jelenlétükkel ujjlenyomatként örzik az egykori természeti környezetre és ember-növény kapcsolatokra vonatkozó információkat. A kunhalmok alatt eltemetett és konzervált talajok fitolittartalmának vizsgálatával rálátást nyerhetünk a halom építése előtti környezet bizonyos vegetációs jellegzetességeire (BARCZI et al., 2009a; BEDE et al., 2014).

Jelen dolgozat célja, hogy a Bán-halom korábban végzett komplex táj- és paleoökológiai felméréséből származó ismeretekre (BARCZI et al., 2009b) építkezve, az eltemetett paleotalaj mintáinak fitolitvizsgálati eredményeivel egészítése ki a halom környezettörténeti és régészeti talajtani értelmezését.

\section{A kutatás előzményei}

Annak érdekében, hogy a bemutatásra kerülő fitolitvizsgálati eredményeket a korábban végzett szerteágazó vizsgálatokba integráljuk (BARCZI et al., 2009b), valamint azok értelmezésénél támaszkodhassunk a halmon végzett geográfiai, geomorfológiai, recens és paleotalajtani adatokra, összefoglaljuk és elemezzük a rendelkezésre álló ismereteket.

Postai cím: PETŐ ÁKOS, Szent István Egyetem, Mezőgazdaság- és Környezettudományi Kar, 2100 Gödöllő, Páter Károly u. 1.E-mail: peto.akos@mkk.szie.hu 
A vizsgálati terület elhelyezkedése és rövid tájföldrajzi jellemzése

A Bán-halom Jász-Nagykun-Szolnok megye területén, a Szolnok-Túri-síkon helyezkedik el, Kenderes település határában. A 80 és 105 méter közötti tengerszint feletti magassággal jellemezhető hordalékkúp-síkság egy része löszszerü üledékkel fedett. A Nagykunság északi részén a pleisztocén folyamán a Bükkből és a Mátrából ideérkező vízfolyások, mint például a Sajó, a Hernád, az Eger, a Laskó vagy a Tarna homokos hordalékkúpot építettek, amelynek közép- és aprószemü homok anyagából a szél változatos domborzatot alakított ki (SOMOGYI, 1967; BORSY, 1989). Az így kialakuló homokbuckás területen többnyire szélbarázdák, hosszanti garmadák, maradékgerincek és deflációs laposok a legjellemzőbb formák (MAROSI és SOMOGYI, 1990; DöVÉNYI 2010). A terület klimatikus viszonyait mérsékelten meleg-száraz, a déli régiókat már igen száraz viszonyok jellemzik.

A vizsgált területen az évi csapadékmennyiség 510-540 mm körül alakul. Az ország egyik legszárazabb vidéke ez a terület. Vízrajzi tekintetben kiemelendő a Tisza és a Hortobágy-Berettyó tájalakító munkája. A terület a Tiszántúli flórajárásba (Cirsium) tartozik. Domináns erdőtársulásainak tekinthetőek a füznyár-éger ligeterdők (Salicetum albae-fragilis), a tölgy-kőris-szil ligeterdők (Querco-Ulmetum hungaricum), továbbá sziki tölgyesek (Pseudivino-Quercetum roboris), tatárjuharos lösztölgyesek (Acerei tatarici-Quercetum). Gyakoriak a szikes mocsarak (Bolboschoenetum maritimi), a sós sivatagi társulások (Suadetum maritimae; Salsoletum sodae), vakszikfoltok (Lepidio-Camphorosmetum), hernyópázsitos rétek (Agrosti-Beckmannietum) (KIRÁLY et al., 2008).

\section{A Bán-halom morfológiája}

A Bán-halom egy északkelet-délnyugati irányban húzódó garmadán helyezkedik el, tengerszintfeletti magassága 89,8 m, amellyel a Nagykunság második legmagasabb pontjának számít. A halomtest anyaga nagy valószínüség szerint az északi előtérben húzódó mesterséges mélyedésből származik. A halomtest közel szabályos kör alapú, bányászati tevékenység eredményeképpen délnyugati oldala sérült. Ezen az oldalán más jellegü erőteljes bolygatásoknak is ki van téve a terület: földutak, taposás, deflációs elhordások és lerakódások, valamint anyagnyerő helyként is használják a halmot (BARCZI et al., 2009b).

A Bán-halom jelenleg geomorfológiai szempontból a megbontott, aszimmetrikus halmok csoportjába tartozik. A térképezés során a halom alapjának kerülete 274 méternek, a területe pedig 0,46 hektárnak bizonyult (1. ábra). 


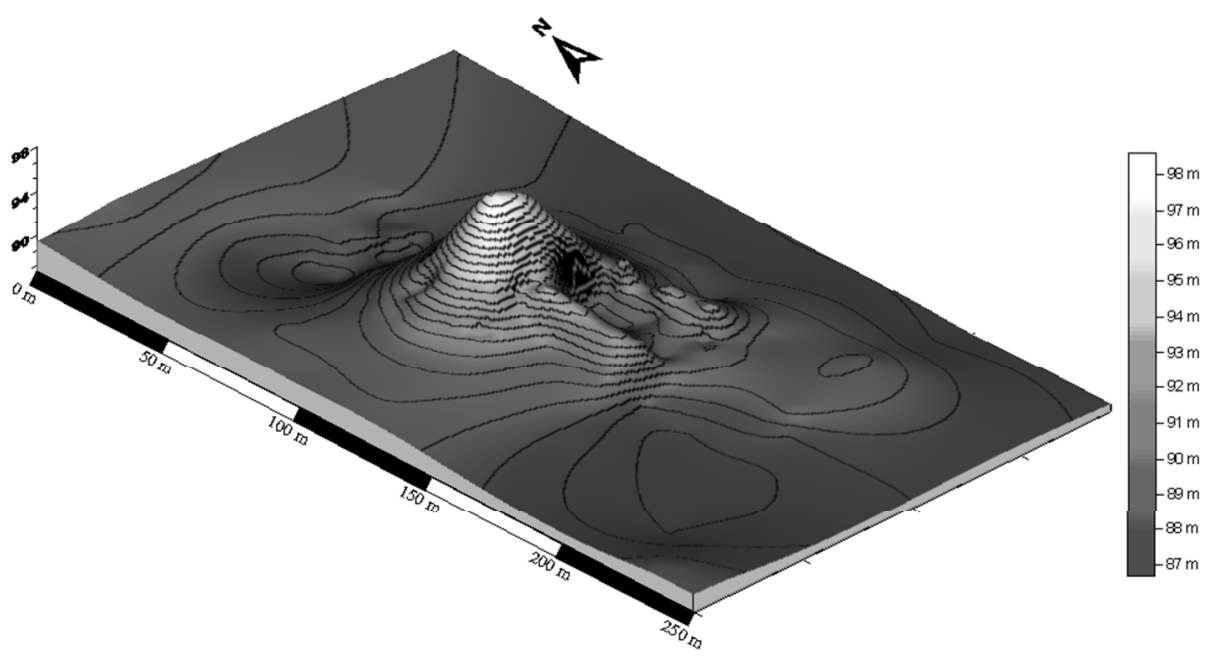

1. ábra

A Bán-halom geomorfológiai jellemzésének érdekében készült domborzati modellje (készítette: TóTH Cs.; BARCZI et al. 2009b alapján)

\section{A Bán-halom környezetének talajtani viszonyai}

A Bán-halmon és annak közvetlen környezetében végzett sekélyföldtani és talajtani fúrások tapasztalatai, valamint a minták laboratóriumi alapadatai rávilágítottak arra, hogy a Bán-halom a lösziszapos környezetből kiemelkedő eolikus homokhátak egyikére épült. Építéséhez a környező területek humuszban gazdag feltalaját használták fel (BARCZI et al., 2009b: 1. táblázat).

\section{A Bán-halom rétegtani viszonyai}

A halomtest egyes rétegeinek leírását BARCZI et al. (2009b) nyomán foglaljuk össze. A halomtest feltalaja a lágyszárú növényzet gyökereivel közepesen átszött, porosan morzsás szerkezetü, sötétbarna színü A-szint (10YR 2/2). A recens B-szint gilisztajáratokban közepesen gazdag, a fásszárúak gyökérzetét szórványosan tartalmazó, gyengén morzsás, közepesen tömődött szint. Színe barnás sötétszürke (10YR 3/1), benne apró szürkés-fehér erek láthatók. A recens talaj mészmentes. A legfelső K4 kultúrréteg, amely 70-180 cm-es relatív mélységben települ. Színben nem üt el a recens talajtól (10YR 3/1), de tömődött, vasszeplőket tartalmazó réteg, amelyben vöröses színü, antropogén eredetű szemcsék figyelhetőek meg. A halom felszínétől számított második K3-as réteg (180-240 cm) fekete színü (10YR 2/1), gyengén kagylós törésű. Antropogén eredetü talajidegen anyagokat tartalmaz (pl. csontszilánkok), a helyenként megjelenő vöröses bekeveredés minden valószínűség szerint patics málladék (vö. PETÖ et al. 2013; 2015). Vasszeplő kevés található benne, annál gyakoribbak viszont a szürkés-fehér porszerü behintések. A K2 réteg 
(240-330 cm) színe egységesen fekete (10YR 2/1). Az előző rétegekhez képest antropogén nyomokat nem tartalmaz, valószínúleg talajból meghordott, poliéderes törésủ réteg. Alatta kevert, intenzív emberi hatásokra utaló nyomokat tartalmazó (paticsmálladék, csontok- és kerámiatöredékek) K1 réteg települ $(330-470 \mathrm{~cm})$. Ebben a rétegben szórványszerüen sárgás foltok is megjelennek.

A halom alatti paleotalaj világosabb, egységesebb színével ( $A_{\mathrm{p}}$-szint: 10YR 3/1; 470-500 cm) jól elkülönül, közepesen tömödött, gyengén poliéderes szerkezetü. Kevés csontmaradvány itt is fellelhető. A $\mathrm{B}_{\mathrm{p}}$-szint $(500-590 \mathrm{~cm}) 540$ cm-től fokozatosan világosodik (10YR 3/2), barnás-fekete színből okkersárga színbe vált. Rozsdafoltokat, lepedéket nem tartalmaz, antropogén eredetü talajidegen anyagoktól mentes. Szerkezet nélküli, alapvetően homok textúrájú. A paleotalaj szénsavas meszet nem tartalmaz. A sárga színủ alapkőzet (10YR 5/3 brown) $C_{1}$ rétege $(590-640 \mathrm{~cm})$ nyomokban tartalmaz meszet, egyenletes szemcsenagyságú homok, amelyben vasmozgás nyomai nem láthatók. 640-690 cmes relatív mélységben egy durvább szemcsézettségü, fakósárga (2.5YR 5/3) homoküledék jelenik meg $\left(\mathrm{C}_{2 \mathrm{fe}}\right)$, amelyben megjelennek a rozsdafoltok, vasszeplők, valamint a szénsavas mésztartalom is.

A halom laboratóriumi vizsgálati adatai eredményesen összevethetők a morfológiai vizsgálatokkal (Az eredményeket BARCZI et al. 2009b nyomán használjuk és összegezzük.) (2. ábra). A teljes halomtest homok textúrájú, a rétegek és a szintek között jelentős különbség a szemcseösszetételben nem mutatkozik, bár az alapkőzet rétegeiben a homokfrakció aránya nő (2. ábra). A recens A-szint semleges kémhatású, mérhető szénsavas meszet nem tartalmaz, humusztartalma a csernozjom jellegü homoktalajoknak felel meg. A B-szintben - bár ez is gyakorlatilag mészmentes - nő a pH (és csökken a vezetőképesség), csökken a szervesanyagkészlet. A K4 kultúrréteg még gyengén lúgos-lúgos kémhatású, a többi kultúrréteg viszont savanyú $\mathrm{pH}$ értékeket mutat és mészmentes (2. ábra). A humusztartalom is váltakozó, a legmagasabb érték a K3 rétegben mérhető, máshol a humuszos feltalajoknak (vagyis a meghordásnak) megfelelö. A paleotalajban a humusz mennyisége, a sótartalom visszaáll a talajképződésnek (v.ö. recens talajszintek) megfelelö értékre, de a pH savas marad. A B-szint csökkenő humusztartalma mellett csökken a vezetőképesség, ugyanakkor nő a $\mathrm{pH}$, és az alapkőzetben megjelenő mésztartalom semleges-lúgos tartományba emeli a kémhatást. A Cszintekben a humusztartalom lecsökken, a mésztartalom nő, a vezetőképesség alacsony értéken marad (2. ábra). A halom rétegeiben mért összes foszfortartalom a kultúrrétegekben és az $\mathrm{A}_{\mathrm{p}}$-szintben legmagasabb, de magas értéket vesz fel a $\mathrm{K} 2$ szintben is, amely az emberi hatásból eredő szerves anyag terhelésre utalhat (2. ábra). 


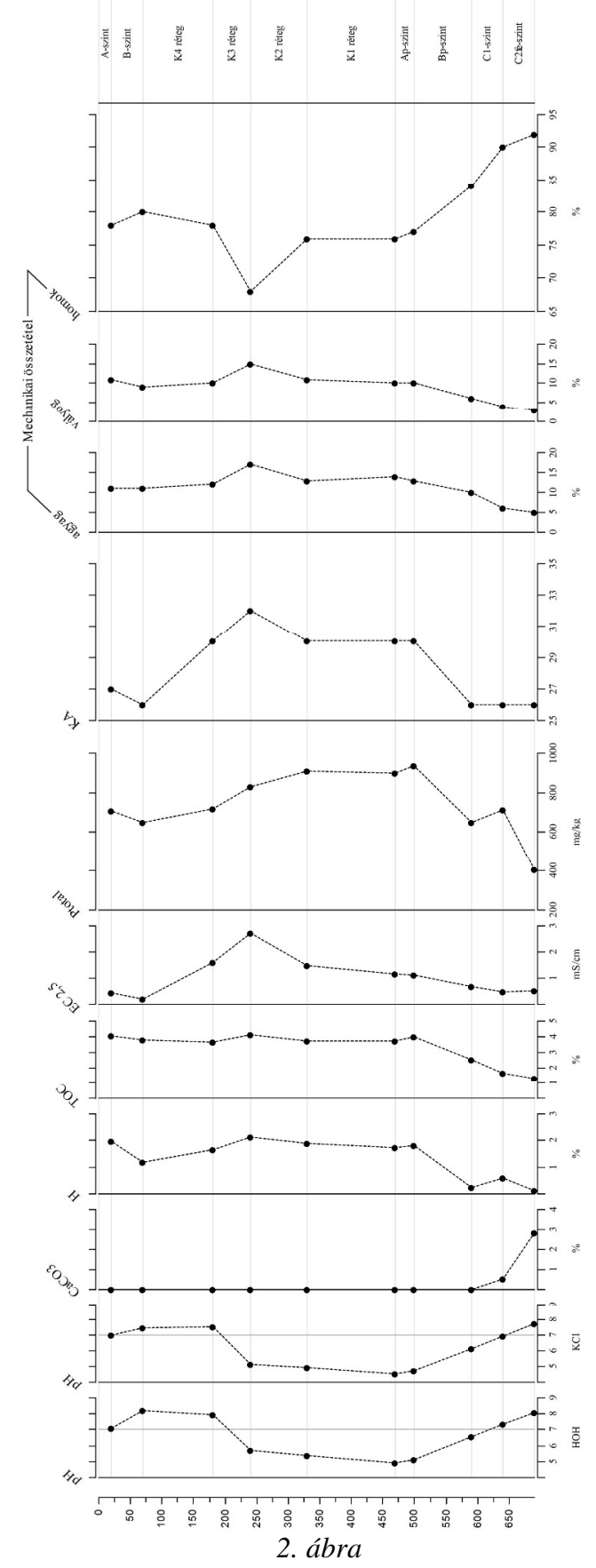

A Bán-halom rétegtani egységein mért talajfizikai és -kémiai paraméterek vertikális eloszlása (BARCZI et al. 2009b nyomán készítette PETÖ Á.) 


\section{Anyag és módszer}

A vizsgált minták származása és a mintagyüjtés módszertana

A Bán-halmon indított sekélyföldtani fúrás a halom középpontjától a halom által eltemetett paleotalaj talajképző kőzetéig hatolt. A mintavétel Eijkelkamp típusú kézi fúróval történt, amely $10 \mathrm{~cm}$-es térközönként tette lehetővé a halom üledékösszletének megmintázását. A mindösszesen $690 \mathrm{~cm}$ mély fúrómagban az eltemetett paleotalajt $470-500 \mathrm{~cm}$-es relatív mélységben harántolta a fúrás (2. ábra). Ennek ismeretében a fúrómagot a 460-510 cm-es intervallumban, $10 \mathrm{~cm}$-es pontsürüséggel mintáztuk meg a fitolitvizsgálat elvégzésének céljából (1. táblázat) (BAKLANOV 2011). A talajtani megfigyelések alapján korábban leírt paleotalaj feletti minta fitolitelemzésének célja, hogy az egykori felszín minél pontosabb meghatározását elvégezhessük. A mintavételi sürüséget az eltemetett talaj homok fizikai félesége indokolta (vö. BOBROVA és BOBROV, 1997; HART és HUMPHREYS, 1997).

\section{1. táblázat}

A fitolitelemzéshez vett minták elhelyezkedése a Bán-halom rétegrendjében (BAKLANOV 2011 nyomán).

\begin{tabular}{|c|c|l|}
\hline Mintavételi mélység $[\mathrm{cm}]$ & Mintakód & \multirow{2}{*}{ Rétegtani helyzete } \\
\hline $460-470$ & Bh47 & K1 \\
\hline $470-480$ & Bh48 & \multirow{2}{*}{$\mathrm{A}_{\mathrm{p}}$-szint } \\
\hline $480-490$ & $\mathrm{Bh} 49$ & \\
\hline $490-500$ & $\mathrm{Bh} 50$ & \\
\hline $500-510$ & $\mathrm{Bh} 51$ & \multirow{2}{*}{$\mathrm{B}_{\mathrm{p}}$-szint } \\
\hline
\end{tabular}

\section{A növényi opálszemcsék feltárásának módszertana}

A növényi opálszemcsék talajból történő feltárását GoLYEVA (1997; 2001), Golyeva és KHOKHLOVA (2003), valamint PEARSALL (2000) nyomán alkalmaztuk. A többlépcsős szeparálási folyamat során a kiindulási talajanyag szervesanyag tartalmát erős oxidálószerrel (cc. $\mathrm{H}_{2} \mathrm{O}_{2}$ ) elroncsoljuk, majd nedves szitálással eltávolítjuk a minták homok frakcióját. Ezt követően gravitációs ülepítéssel a minták agyagtartalmát a lehető legalacsonyabbra csökkentjük.

Az elemzés során feltárt és meghatározott növényi opálszemcsék megnevezése az International Code for Phytolith Nomenclature (ICPN 1.0) (MADELLA et al., 2005) nevezéktani rendszert követte. A nemzetközi fitolit nómenklatúra segítségével az egyes növényi opálszemcséket (legfeljebb) három jelzővel, illetve azok kombinációival jelöltük meg. Amennyiben nem teljes szöveti elkovásodással, 
hanem egymagában megfigyelt ún. diszartikulált, elkovásodott növényi sejtről volt szó, akkor megadtuk a szemcse:

- pontos alakját egy két- (2D), vagy egy háromdimenziós (3D) jelző segítségével;

- textúráját, illetve felszíni mintázatát az ICPN 1.0 listában szereplő jelzők segítségével, illetve

- a növényi opálszemcse anatómiai származását, amennyiben az egyértelmü és kétségtelenül meghatározható volt.

Az adatok értelmezése érdekében az egyes morfotípusokhoz a Golyeva-féle osztályozási rendszer útmutatása (GOLYEVA 1997, 2001, 2007) alapján rendeltünk környezeti információt, illetve a hazai talajtani alapokra építkező fitolitvizsgálati kutatások eredményeit is igyekeztünk beépíteni (РETÖ 2011; 2013; PETŐ és BARCZI, 2010a, 2010b, 2011). Mivel mindkét osztályozás tipológiai alapú, így az adatok értelmezésében nem csak az egyes morfotípusokat kell figyelembe venni, hanem az egy mintán belül megjelenő morfotípus csoportok eloszlását, illetve azok egymáshoz viszonyított arányát.

\section{Vizsgálati eredmények és megvitatásuk}

A Bán-halom eltemetett talajának $A_{p}$ - és részben $B_{p}$-szintjeiből, valamint a paleotalaj és az első kultúrréteg (K1) határrétegéről $10 \mathrm{~cm}$-es mintázási intervallummal gyüjtött talajminták fitolitvizsgálati adatai elsődlegesen az egykori környezet jellegzetességeivel kapcsolatban szolgáltatnak paleoökológiai adatokat. Az eltemetett paleotalaj közepesen tömődött anyaga, színe és gyengén poliéderes szerkezete alapján jól elkülönül a felette települő, antropogén hatásokat magánviselö kultúrrétegtől. Ugyanakkor - és ez többek között a Bán-halom területének emberi bolygatásáról is árulkodik - a paleotalaj $\mathrm{A}_{\mathrm{p}}$-szintjében - amely a halom csúcspontjától számított $470 \mathrm{~cm}$-es relatív mélységben helyezkedik el csonttöredékek és emberi megtelepedésre utaló antropogén szemcsék kerültek elő a fúrás anyagából. Ennek nyomai azonban már az eltemetett paleotalaj $\mathrm{B}_{\mathrm{p}}$-szintjében nem jelentkeztek. Ezen terepi megfigyelések alapján okkal feltételezhetjük, hogy a fúrással nyert minták ténylegesen az egykori felszínt jelenítik meg, valamint hogy ez a felszín emberi behatás nyomait viselte magán az építkezés megkezdése előtt. 


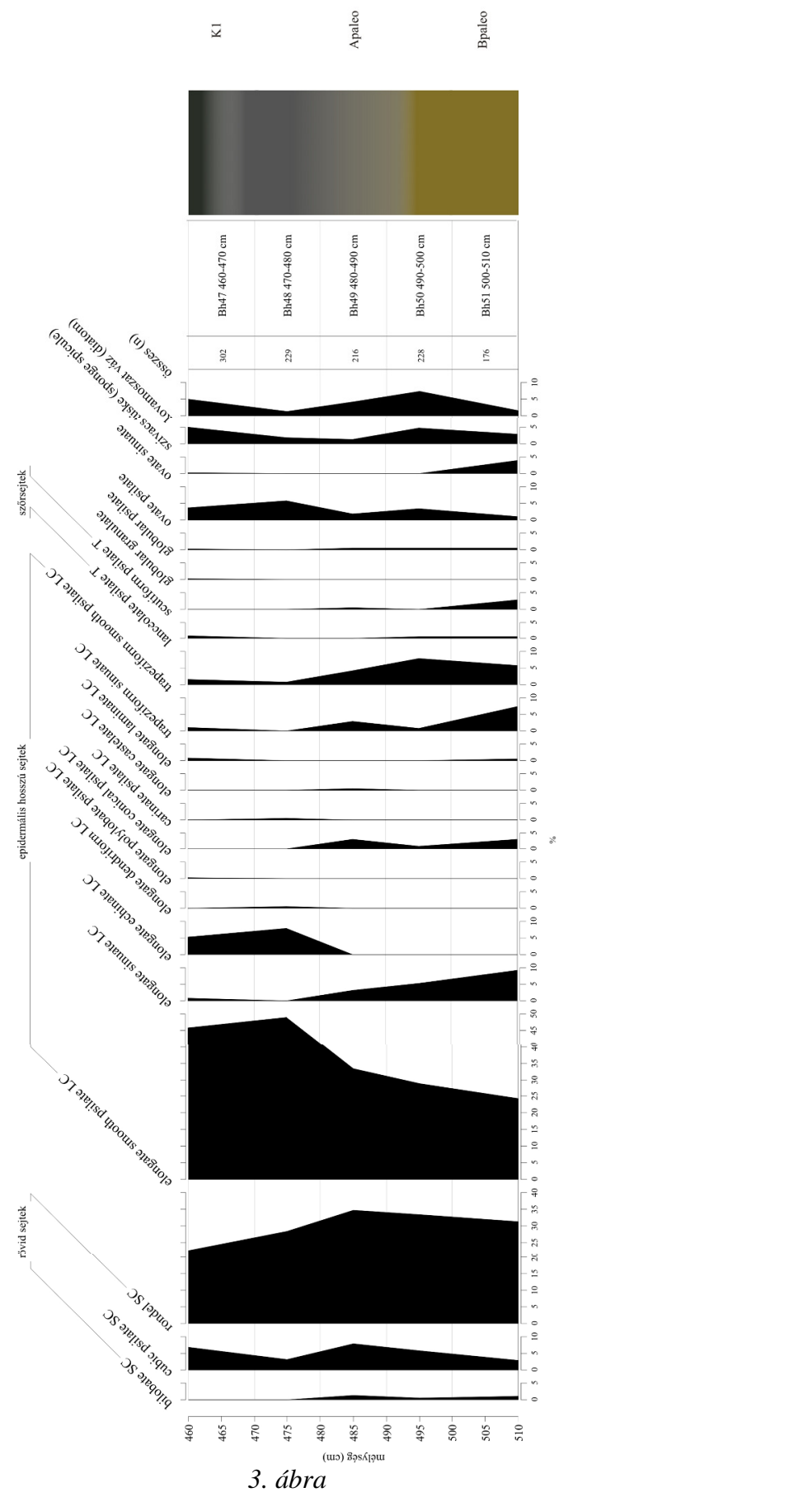

A Bán-halomból származó minták fitolitvizsgálati eredményét bemutató eloszlásgrafikon. 
Az elemzésbe vont minták fitolit mennyiségében szignifikáns eltéréseket nem tapasztaltunk. Minden mintában kellő mennyiségü (3. ábra), közepesen jó megtartású növényi opálszemcsét figyeltünk meg és írtunk le (4. ábra).
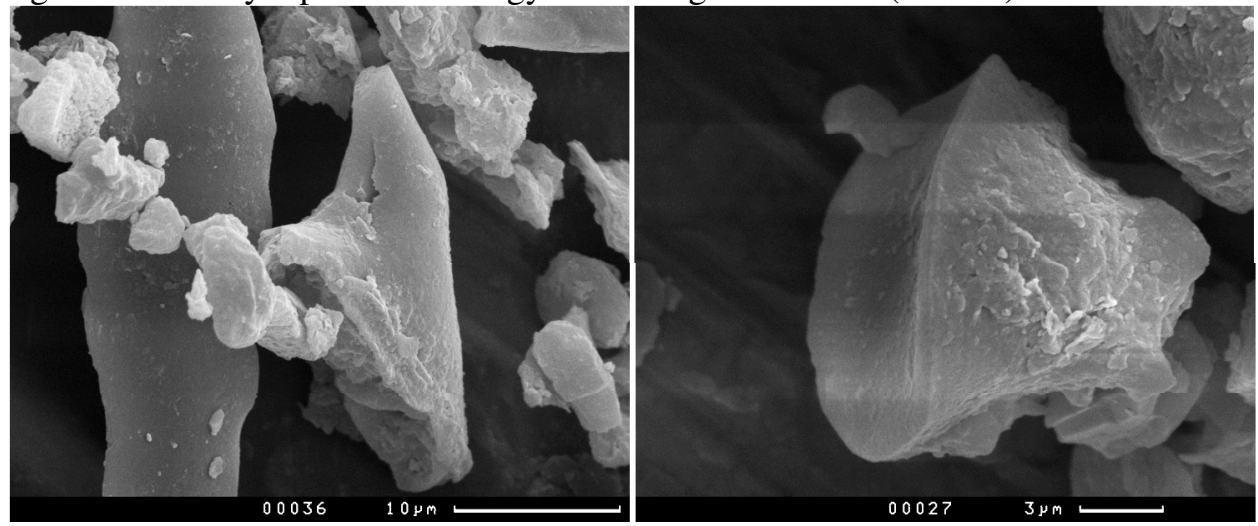

a) Lanceolate psilate T fitolit morfotípus SEM

b) Rondel SC fitolit morfotípus SEM felvétele. felvétele.

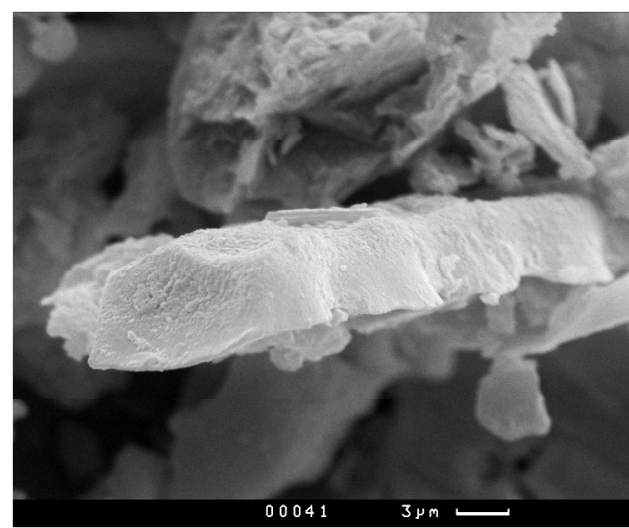

c) Trapeziform sinuate LC fitolit morfotípus SEM felvétele.

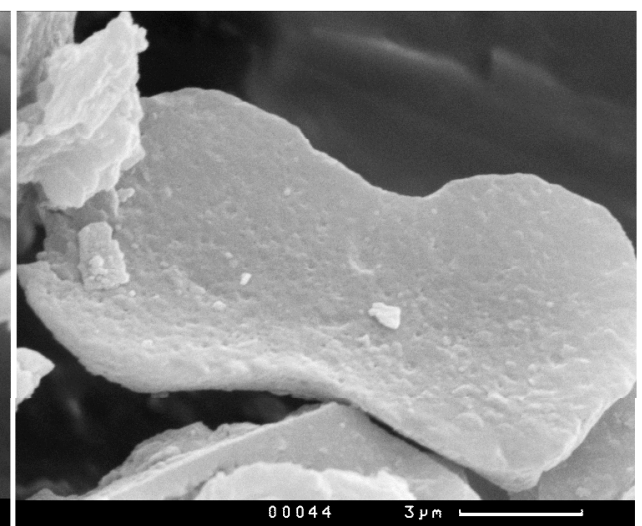

d) Bilobate SC fitolit morfotípus SEM felvétele.

\section{4. ábra}

A Bán-halom eltemetett paleotalajának $A_{\mathrm{p}}$-szintjéből (470-500cm) származó minták fitolitvizsgálata során megfigyelt egyes fitolit morfotípusok SEM képei.

Az elemzésbe vont minták közül a Bh48-as (470-480 cm, vö. 1. táblázat) jeleníti meg a paleotalaj felszínét, amelyet jól kirajzol a mintasorozatban legmagasabb értéket adó elongate smooth psilate $L C$ általános, biomassza produkciót jelző morfotípus itt jelentkező legmagasabb értéke (3. ábra). Ehhez társul, a lefelé irányuló elmozdulásnak feltehetően hasonlóan ellenálló elongate echinate $L C$ kumulációja is a vizsgált rétegsorban (3. ábra). 
A vizsgálati anyagunk homok fizikai féleségü - 77\%-os homoktartalommal bír - amelynek makropórusaiban a kisebb méretü, izodiametrikus formák lefelé történő elmozdulása feltehetően könnyebben valósul meg, mint az elnyújtott, elongate típusú sejteké. Talán részben ennek is tudható be, hogy a megfigyelt epidermális rövid sejtek mindegyike a Bh49-es (480-490 cm, vö. 1. táblázat) mintában éri el maximumát (3. ábra). Ezek közül a rondel $S C$ morfotípus a sztyeppei életközösségek egyik indikátora (GOLYEVA 1997, 2001, 2007) (4. ábra). Korábban bizonyítást nyert az is, hogy a sztyeppei élöhelyek alatt fejlődött talajokban a rondel $S C$ és az elongate smooth psilate LC aránya a rondel SC irányában eltolódhat (PETÖ és BARCZI, 2011; PETŐ 2013). A halom építése elötti környezet - fitolitok alapján történő - rekonstruálásában kiemelkedő szerepet játszik ez a morfotípus. Nemcsak a minden mintában megjelenő magas részarány, hanem a Bh49-es $(480-490 \mathrm{~cm}$, vö. 1. táblázat) mintában a rondel SC és az elongate smooth psilate $L C$ arányának eltolódása jelöli ki a halom építése elötti terület sztyeppei élőhelyi dominanciáját. Ezekhez a megfigyelésekhez társul még az elongate laminate $L C$ morfotípus előkerülése is, amely jelen ismereteink szerint a sztyeppei életközösségek alatt fejlődött talajok sajátja (PETÖ, 2013: Fig. 8.). Csupán az említett hosszú sejt típusra nem alapozhatnánk feltevéseinket, mert ez idáig csupán egyetlen csernozjom talajból jelentették előfordulását (PETŐ és BARCZI 2011), de megjelenése a mintasorozatban alátámasztja a korábban megfogalmazottakat.

Ugyanebben rétegben került elő egy, a gabonák egykori jelenlétét valószínüsítő morfotípus. Az elongate dendritic LC morfotípus az óvilági gabonák toklászának (lemma és palea) és pelyvalevelének (gluma) börszövetével hozható összefüggésbe (többek között: Miller Rosen 1992; BALL et al. 1996, 1999). Az elongate dendritic $L C$ mellett a szántó mủvelési ág alatt felvett talajok sajátjaként tekinthetünk az ovate morfotípusokra, amelyek több ponton is jelentkeztek a halom rétegrendjében. A szóban forgó morfotípusok anatómiai hovatartozását nem tudjuk biztosan meghatározni, ugyanakkor megjelenésük egy adott mintában összefüggésben állhat a gabonák egykori jelenlétével. Ennek egyik közvetett bizonyítéka, hogy PETỎ (2013: Fig. 8) a szántó alatt felvett talajok mintáiban kimutatta a trapeziform SC morfotípusokat, amelyek nagy fokú hasonlóságot mutatnak a Bán-halom mintáiból feltárt és jelen dolgozatban cubic psilate SC megnevezéssel jelölt epidermális rövidsejt típushoz.

A fent említett megfigyelések közül minden kétséget kizáróan csupán az elongate dendritic LC morfotípus megjelenésére támaszkodhatunk, amikor felvetjük, hogy a halom építése elötti környezetben gabonák jelenlétével kell számolni. Valószínüleg ugyanakkor ez nem gabona- vagy szántóföld jelenlétét feltételezi, hanem annak lehetöségét veti fel, hogy az építési területen korábban okkal, vagy véletlenül gabonát helyeztek el, használtak fel. Az elongate dendritic LC megjelenése a mintákban többek között azért is izgalmas, mert a halom feltehetóen egy lakódomb volt, amelyet az egyes rétegekben mért antropogén hatásokat jelölő indikátorok változatossága is alátámaszt (pl.: összes foszfor tartalom eloszlása a halom rétegeinek mentén, vö. 2. ábra). Mint ilyen, okkal feltételezhetjük, hogy a gabonák jelenléte a megtelepedési területen fontos régészeti információt közvetíthet. A másik ok, amiért kiemelendő az elongate dendritic LC 
megjelenése, hogy az eddig megvizsgált halmok egyikénél sem tudtuk kimutatni ezt a morfotípust (PETŐ és BuCSI, 2008; PeTŐ és CUMMINGS, 2011).

Nemcsak a háziasítással bekerülő növényfajok lehetséges jelenléte, hanem a morfotípusok vertikális eloszlásának enyhén kevert megjelenése is felveti az erős emberi hatás meglétét az egykori építési felszínen.

A Kárpát-medence holocénkori természetes környezetének rekonstruálásában mindig kiemelkedően fontos szerepet játszott annak nyomozása, hogy az Alföldet milyen mértékben boríthatta zárt erdőtakaró (többek között: BARCZI et al. 2006a, 2006b, 2009; SÜMEGI et al. 2012). A Bán-halom eltemetett talajának fitolitvizsgálati anyagában a lanceolate psilate $T$ morfotípust, valamint a globular morfotípusokat köthetjük az erdei vegetáció egykori jelenlétéhez. Mindhárom esetben azonban rendkívül alacsony a részarányuk az egyes vizsgálati rétegekben (3. ábra), amely az „erdő szignál” gyengeségét, azaz a halom építése elötti környezetben a zárt erdei vegetáció hiányát feltételezi.

A 3. ábra utolsó két oszlopa mutatja a mintákban mért szivacstüske és kovamoszat vázak részarányát. Mindkét kovavázas indikátor a víztöbblet hatására fejlődött térszínek sajátja, amely alapján feltételezhetnénk a halom építése előtti környezet erős vízhatását. Ugyanakkor figyelembe kell venni a talajképződés alapkőzetének genetikáját is. Feltételezhető ugyanis, hogy a redoxi folyamatok jeleit egyáltalán nem viselő üledékösszlet eredeti képződési helyével hozható összefüggésbe a szivacstüskék és a kovamoszat vázak megjelenése és az nem a halom egykori környezetére vonatkoztatható. Az alapkőzet - talajképződés megindulása előtti - áthalmozódásával a halom egykori területére kerülő kovavázas indikátorok jelentéstartamának megítélése azért is bírhat kiemelt szereppel, mert nem feltételezhetjük, hogy egy erősen hidromorf talajképződéssel jellemezhető területrészt választott volna ki a kor embere a letelepedés, vagy akár temetkezés céljára. Ahogy ezt korábbi vizsgálatok bizonyították, a halmok építésének helyszínei a környezet legmagasabb, legszárazabb pontjain, löszhátakon, homokbuckák tetején, a tájból enyhén kiemelkedő alluviális szigeteken voltak.

\section{Összefoglalás}

A kunhalmok az eurázsiai sztyeppe öv síkvidéki tájának emberalkotta formakincsei. A halmok építésekor az azt létrehozó ember eltemette és ezáltal konzerválta a korabeli táj egyik legfontosabb "olvasókönyvét", a járószint talajtakaróját. Az egykori tudatos emberi cselekvés - azaz különböző céllal létesített halmok megépítésének - kiemelten fontos mellékterméke, hogy a halmok alatti terület korabeli talajtakarója izolálódott a környezeti hatásoktól és ezáltal megőrződött.

Tanulmányunkban a Szolnok-Túri-síkon található Bán-halmon végzett geomorfológiai, botanikai, talaj- és rétegtani eredményeket foglaljuk össze, illetve egészítjük ki az eltemetett paleotalaj mintáin végzett fitolitelemzés eredményeivel. A növényi opálszemcsék ellenálló képessége - egyéb mikro- és makroszkopikus, szervesanyagú növényi eredetü maradvánnyal szemben - lehetőséget ad a fitolitelemzés módszerének széleskörủ paleoökológiai alkalmazására. A növényi 
szövetböl történő feltáródásukat követően még hosszú ideig extrém körülmények között is fennmaradnak a befoglaló közegükben: megőrzik a képződési körülményeikre jellemző formájukat, anatómiai származásukra vonatkozó tulajdonságukat, textúrájukat. Ezzel megteremtik a lehetőségét, hogy a fitolitkutatás a paleoökológia és paleotalajtan tudományában, mint önálló kutatási irányzat szerepet kapjon. A növényi opálszemcsék a talajok fejlődéstörténetének hírmondói is egyben, így a megfelelő peremfeltételek teljesülése esetén egy-egy talajszelvény képződését is jellemezhetjük a módszer felhasználásával.

A Bán-halom rétegtani vizsgálatát a halmon végzett sekélyföldtani fúrás által szolgáltatott fúrómagok morfológiai, illetve alapvető laboratóriumi vizsgálatai alapján lehet felvázolni. Eszerint a halom palástját adó recens talajképződmény alatt legalább négy, morfológiailag jól elkülönülö kultúrréteg helyezkedik el, amely alatt 470 cm-es relatív mélységben található az építés előtti járószint, azaz az eltemetett paleotalaj felszíne.

Az eltemetett talaj $A_{p}$ - és részben $B_{p}$-szintjéből, valamint a paleotalaj és kronológiai értelemben - az első kultúrréteg (K1) határrétegéből $10 \mathrm{~cm}$-es mintázási intervallummal gyüjtött talajminták fitolitelemzése szerint a Bán-halom építése előtti környezetet erős felszínbolygatás érthette. Ellentétben a temetkezési dombokon (kurgánokon) végzett - hasonló metodikájú - vizsgálatokkal, jelen esetben feltételezzük a halom alatti terület korábbi használatba vételét, a megtelepedést. Ennek egyik legfontosabb bizonyítéka a gabonák egykori jelenlétére utaló fitolit morfotípusok megjelenése a mintákban. Mindemellett az eltemetett paleotalaj morfotípus spektruma azt támasztja alá, hogy a halom építési pontjának környezetében a természetes vegetációt a környezö homokbuckák sztyeppei, félszáraz vegetációja uralta, amelyben fás szárú fajok egykori megjelenése, illetve dominanciája nem rekonstruálható.

Kulcsszavak: növényi opálszemcsék elemzése, régészeti talajtan/geoarcheológia, kunhalom, környezettörténet, eltemetett talajok

\section{Köszönetnyilvánítás-Együttműködés}

A SEM felvételek elkészítésében nyújtott segítségért köszönet illeti Dr. Alexandra A. Golyevát (Orosz Tudományos Akadémia, Földrajztudományi Kutató Intézet). 


\section{Irodalom}

AleXANDROVSKIY, A.L., GolYeVA, A.A., GunOVA, V.S., 1997. Reconstruction of paleolandscape conditions of early Scythian soils in Stavropol' refion. Eurasian Soil Science 30. 533-542.

BAKLANOv, Sz., 2011. A Bán-halom eltemetett talajának fitolitvizsgálati eredményei. Publikálatlan Szakdolgozat, Szent István Egyetem, Mezögazdaság és Környezettudományi Kar, Természetvédelmi és Tájökológiai Tanszék, Gödöllő. 56.

Ball, T.B., Gardner, J.S., BRotherson, J.D., 1996. Identifying phytoliths produced by the inflorescence bracts of three species of wheat (Triticum monococcum L., T. dicoccon Schrank., and T. aestivum L.) using computerassisted image and statistical analyses. Journal of Archaeological Science 23. 619-632.

BALl, T.B., GARDNER, J.S., ANDERSON, N., 1999. Identifying inflorescence phytoliths from selected species of wheat (Triticum monococcum, T. dicoccon, $T$. dicoccoides, and T. aestivum) and barley (Hordeum vulgare and $H$. spontaneum) (Gramineae). American Journal of Botany 86 (11). 1615-1623.

Barczi, A., Tóth, T.M., Csanádi, A., SÜMegi, P., CZinkotai, I. 2006a. Reconstruction of the paleo-environment and soil evolution of the Csípöhalom kurgan, Hungary. Quaternary International. 156-157. 49-59.

BARCZI, A, JoÓ, K., PETÖ, Á., BUCSI, T. 2006b. Survey of the buried palaeosol under Lyukas-mound. Eurasian Soil Science. 39(1). 133-140.

BarcZi, A., GolyeVA, A.A., PeTő, Á. 2009a. Palaeoenvironmental reconstruction of Hungarian kurgans on the basis of the examination of palaeosoils and phytolith analysis. Quaternary International 193. 49-60.

BARCZI A., TótH Cs., TóTH A., PETŐ Á. 2009b. A Bán-halom komplex tájökológiai és paleotalajtani felmérése. Tájökológiai Lapok 7(1). 191-208.

BARCZI, A., JoÓ, K., 2009. The role of Kurgans in the palaeopedological and palaeoecological reconstruction of the Hungarian Great Plain. Zeitschrift für Geomorphologie. 53(1). 131-137.

Bede Á., Csathó A.I., CZuKor P., SÜMEgi P. 2014. A hortobágyi Ecse-halom geomorfológiai, tájtörténeti, botanikai, szedimentológiai és mikromorfológiai vizsgálatának elözetes eredményei. In: Környezetföldtani és környezettörténeti kutatások a dunai Alföldön (Szerk.: SÜMEGI, P.) GeoLitera, SZTE TTIK Földrajzi és Földtani Tanszékcsoport, Szeged. 29-41.

Bobrova, E. \& Bobrov, A., 1997. Phytoliths in soils: Species composition, distribution along a soil profile, and value as environmental indicators. In: Monografías del Centro de Ciencias Medioambientales, CSCI (4). The Stateofthe-art of Phytholits in Soils and Plants. (Eds.: PINILla, A., JUAN-TRESSERAS, J. \& MACHADO, M. J.) 5-13. Madrid.

BORSY Z., 1989. Az Alföld hordalékkúpjainak negyedidőszaki fejlődéstörténete. Földrajzi Értesítö 38. 211-224.

DÖVÉNYI Z. (szerk.), 2010. Magyarország kistájainak katasztere. Budapest. MTA Földrajztudományi Kutatóintézet. 876. p. 
Golyeva, A. A., 1997. Content and distrubution of phytoliths in the main types of soils in Eastern Europe. In: Monografías del Centro de Ciencias Medioambientales, CSCI (4). The State-of-the-art of Phytholits in Soils and Plants. (Eds.: Pinilla, A., Juan-Tresseras, J. \& Machado, M. J.) 15-22. Madrid.

Golyeva, A. A., 2001. Biomorphic analysis as a part of soil morphological investigations. Catena. 43. 217-230.

GolyeVA, A. A., 2007. Various pytolith types as bearers of different kinds of ecological information. In: Madella, M., Zurro, D. (Eds.), Plants, People and Places, Recent Studies in Phytolith Analysis. Oxbow Books, Oakville, pp. 196-201.

Golyeva, A. A. \& KhoKhlova, O. S., 2003. Biomorphic indicators of humaninduced transformation of soils under early nomad burial mounds in southern Russia. Revistas Mexicana de Ciencias Geológics. 20. (3) 283-288.

FüleKY, Gy., KovÁCs, G., VICZE, M., 2015. Investigation of a Bronze Age tell using soil analysis data. Agrokémia és Talajtan 64(2). 421-435.

HART, D.M. \& HuMPhREYS, G.S. 1997: The mobility of phytoliths in soils; pedological considerations. In: Monografías del Centro de Ciencias Medioambientales, CSCI (4). The State-ofthe-art of Phytholits in Soils and Plants. (Eds.: Pinilla, A., JuAn-Tresseras, J. \& MACHADO, M.J.) 93-100. Madrid.

KIRÁLy G., MOLNÁR ZS., BÖlÖNI J. \& VOJTKÓ A., 2008. Magyarország földrajzi kistájainak növényzete. MTA Ökológiai és Botanikai Kutatóintézete, Vácrátót.

KovÁCs G. 2006. A talajban előforduló régészeti anyagok mikromorfológiai vizsgálata. Agrokémia és Talajtan. 55(2). 499-514.

Madella, M., AleXANDre, A., BALl, T., 2005. International code for phytolith nomenclature 1.0. Annals of Botany 96. 253-260.

MAROSI S. \& SomogYi S. (szerk.), 1990. Magyarország kistájainak katasztere. Magyar Tudományos Akadémia Földrajztudományi Kutató Intézet. Budapest.

Miller Rosen, A.,1992. Preliminary identification of silica skeletons from near eastern archaeological sites: an anatomical approach. In: Rapp, G., Mulholland, S.C. (Eds.), Phytolith Systematics. Emerging Issues. New York, 129-147

Pearsall, D. M., 2000. Paleoethnobotany. A Handbook of Procedures. Academic Press. London

PETŐ Á., 2011. Hazai talajszelvények fitolit morfotípus-diverzitása. Agrokémia és Talajtan 60(1). 45-64.

PETŐ, Á., 2013. Studying modern soil profiles of different landscape zones in Hungary: An attempt to establish a soil-phytolith identification key. Quaternary International 287. 149-161.

PETŐ Á. \& BARCZI A., 2010a. A Magyarországon előforduló meghatározó jelentőségű és gyakori talajtípusok fitolit profiljának katasztere I-II. Módszertani megfontolások, illetve a vizsgált váz- és kőzethatású talajok eredményei. Tájökológiai Lapok 8(1). 157-206. 
PETŐ Á. \& BARCZI A., 2010b. A Magyarországon előforduló meghatározó jelentőségü és gyakori talajtípusok fitolit profiljának katasztere III. A vizsgált barna erdőtalajok eredményei. Tájökológiai Lapok 8(3). 457-495.

PETŐ Á. \& BARCZI A., 2011. A Magyarországon előforduló meghatározó jelentőségủ és gyakori talajtípusok fitolit profiljának katasztere IV. A vizsgált csernozjom és szikes talajok eredményei. Tájökológiai Lapok 9(1). 147-190.

PETÖ Á. \& BUCSI T, 2008. Kiegészítő adatok a Csípö-halom paleoökológiai elemzéséhez. Tájökológiai Lapok 6(1-2). 197-208.

PetÖ, Á. \& CummingS L.S., 2011. Palaeovegetational reconstruction of the Hajdúnánás-Tedej-Lyukas-halom based on combined micropalaeobotanical analysis. In: Pető Á. \& Barczi A. (Eds.) Kurgan Studies: An environmental and archaeological multiproxy study of burial mounds in the Eurasian steppe zone. BAR International Series 2238, pp. 315-325.

PETŐ Á., KENÉZ Á. \& REMÉNYI L., 2013Régészeti talajtani kutatások Perkáta, Forrásdűlő bronzkori földváron. Agrokémia és Talajtan. 62(1). 61-80.

Petö Á., Serlegi G., Krausz E., Jaeger, M., Kulcsár G. 2015. Régészeti talajtani megfigyelések "Kakucs-Turján mögött" bronzkori lelőhelyen I. Agrokémia és Talajtan 64(1). 219-237.

PIPERNO, D. R., 2006. Phytoliths: A Comprehensive Guide for Archaeologists and Paleoecologists. AltaMira Press, Lanham.

Retallack, G. J., 2001. Soils of the past. An introduction to paleopedology. Blackwell Science. Oxford, UK.

SÜMEGI P., GULYÁS S., PERSAITS G., SZELEPCSÉNYI Z. et al. 2012. Az erdőssztyepp hosszú távú fejlődése az Alföld-ön paleoökológiai adatok alapján. Sokarcú klímaváltozás (Szerk.: RAKONCZAI, J.; LADÁNYI, Zs. \& PÁL-MOLNÁR, E.). GeoLiterra, Szeged, 7-24.

SOMOGYI S. 1967. Ösföldrajzi és morfológiai kérdések az Alföldről. Földrajzi Értesítő 16: 319-337.

SZENDREI G. 2012. Talajásványtan, mikromorfológia. Agrokémia és Talajtan. 61(Supp). 93-120.

Tóth, Cs. A., Pethe, M., HATHÁZI, Á., 2014. The application of earth science-based analyses on a twin-kurgan in Northern Hungary. Carpathian Journal of Earth and Environmental Science 9(1). 11-20.

VÁRALlYAY, GY., 2002. A talaj multifunkcionalitásának szerepe a jövő fenntartható mezőgazdaságában. „A növénytermelés szerepe a jövő multifunkcionális mezőgazdaságában. Ötven éves az Acta Agronomica Hungarica. Jubileumi tudományos ülés, 2002. XI. 19. Martonvásár, 13-25. 


\title{
Data on the paleoecological and geoarchaeological examination of the Bronze Age mound known as 'Bán-halom'
}

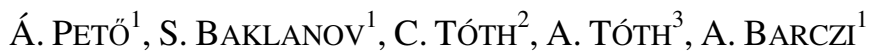 \\ ${ }^{1}$ Department of Nature Conservation and Landscape Ecology, Institute of Nature \\ Conservation and Landscape Management, Szent István University, Gödöllö, \\ Hungary \\ ${ }^{2}$ Department of Geography and Geoinformatics, University of Debrecen, Debrecen, \\ Hungary \\ ${ }^{3}$ Department of Rural Development and Landscape Management, Faculty of \\ Mechanical Engineering and Agriculture, College of Szolnok, Szolnok, Hungary
}

Kurgans and tells are valuable man-made geomorphological formations in the Eurasian steppe zone. During the construction of these formations, humans buried and thus preserved one of the most important sources of information about the ancient environment: the surface soil cover. This conscious human act - the erection of these earthen features - isolated the original soil and therefore kept it in an untouched condition for later eras.

This study gives an overview of the geomorphological, botanical, soil and stratigraphical survey conducted on the Bán-halom and complements it with the results gained from the phytolith analysis of soil samples collected from the buried soil. The fact that plant opal particles are highly resistant to weathering enables phytolith analysis to be utilised widely in paleoecological studies. After the liberation of these inorganic particles from the plant tissue, they persist in the embedding geological media for a long time and keep their original shape, texture and information on their anatomical origin. Phytoliths are not only used as a separate scientific tool in paleoecology, but they may also provide information on the development of soils, thus making them suitable for paleopedological studies.

The stratigraphy of the Bán-halom was described on the basis of a morphological description of core samples collected during the shallow geological coring of the mound, and on the results of basic physical and chemical soil analysis on samples collected from the coring. According to these data, at least four, morphologically distinct cultural layers can be identified below the recent soil cover of the mound. The original surface (paleosol) on which the mound was built can be found below these, at a relative depth of $470 \mathrm{~cm}$.

Based on the phytolith analysis of the buried $A_{p}$ and $B_{p}$ horizons, the area where the mound was built had already been subject to anthropogenic disturbance. Unlike the results obtained from the phytolith analysis of burial mounds (kurgans) in the Great Hungarian Plain, it appears that the area under the Bán-halom was used and disturbed before the mound was erected or established. Some of the most important evidence for this is the presence of cereal- related phytolith morphotypes in the samples. The morphotype spectrum of the samples points to an open grassland habitat in the close vicinity of the examined area; evidence of forest vegetation or the presence of arboreal species was not detected. 
Figure 1. Geomorphological model of Bán-halom (compiled by C. TóTH; source: BARCZI et al. 2009)

Figure 2. Vertical distribution of the soil physical and chemical data obtained by analysing samples collected from the shallow geological coring of the Bánhalom (modified after BARCZI et al. 2009b).

Figure 3. Results of phytolith analysis on samples of buried soil from Bánhalom.

Figure 4. SEM images of phytolith morphotypes recovered from the $A_{p}$ horizon (relative depth: 470-500 cm) of Bán-halom.

Table 1. Samples collected for phytolith analysis and their position in the stratigraphy of Bán-halom.

Keywords: Analysis of plant opal particles, geoarchaeology, mound, paleoecology, buried soils 